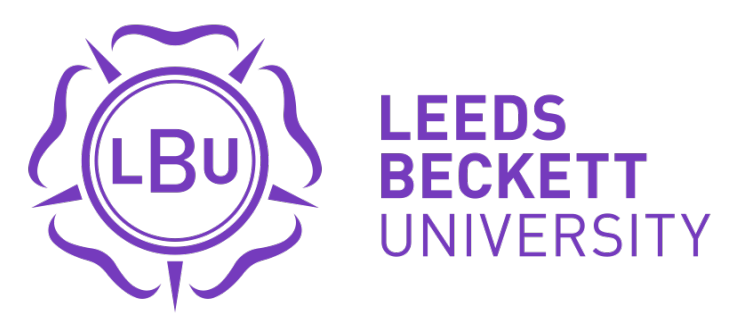

\title{
Citation:
}

Font, X and Elgammal, I and Lamond, I (2016) Greenhushing: the deliberate under communicating of sustainability practices by tourism businesses. Journal of Sustainable Tourism. DOI: https://doi.org/10.1080/09669582.2016.1158829

Link to Leeds Beckett Repository record:

https://eprints.leedsbeckett.ac.uk/id/eprint/2355/

Document Version:

Article (Accepted Version)

The aim of the Leeds Beckett Repository is to provide open access to our research, as required by funder policies and permitted by publishers and copyright law.

The Leeds Beckett repository holds a wide range of publications, each of which has been checked for copyright and the relevant embargo period has been applied by the Research Services team.

We operate on a standard take-down policy. If you are the author or publisher of an output and you would like it removed from the repository, please contact us and we will investigate on a case-by-case basis.

Each thesis in the repository has been cleared where necessary by the author for third party copyright. If you would like a thesis to be removed from the repository or believe there is an issue with copyright, please contact us on openaccess@leedsbeckett.ac.uk and we will investigate on a case-by-case basis. 


\title{
JOST2885FR
}

\section{Greenhushing: the deliberate under communicating of sustainability practices by tourism businesses}

\begin{abstract}
Greenhushing selectively communicates fewer pro-sustainability actions by businesses than are practiced; based on a perception of customers' rights to consumerism. We first studied the gap between the communication of sustainability practices in the audits and websites of 31 small rural tourism businesses in the Peak District National Park (UK). The analysis showed that businesses only communicate $30 \%$ of all the sustainability actions practiced. Their websites emphasised customer benefits, using explicit, affective, experiential and active language that legitimises the customers' hedonistic use of the landscape, while downplaying complex issues and normalising sustainability to reduce customer guilt. Just one website mentioned climate change. We found that greenhushing results from a low moral intensity, masking potentially negative consequences of perceived lower competence, whilst protecting business from more cynical consumers who may interpret their statements as hypocritical. Subsequent textual analysis and interviews were used to understand how communication constitutes these organisations. We propose that greenhushing reshapes and constitutes tourism businesses through their communications. Moreover, greenhushing is a form of public moralisation that adopts communication practices similar to greenwashing, reflecting the social norms expected from a business; however, in this case, located in a moral muteness, rather than moral hypocrisy, that businesses accept but resent.
\end{abstract}

\section{Keywords}

Sustainability, ethics, rural, discourse analysis, rhetoric, greenwashing

\section{INTRODUCTION}

Most readers will be familiar with the issues surrounding "greenwashing". Fewer readers will be familiar with "greenhushing" - the converse of greenwashing - the deliberate withholding, from customers and stakeholders, of information about the sustainability practices that they employ. This paper explores why and how greenhushing is used, and its implications.

Businesses normally communicate their sustainability practices in an attempt to create a positive impression in the minds of their stakeholders. Their objective is to influence their stakeholders' behaviour towards the business and its products or services in line with their business goals, which can include increased financial gain for the business or increased societal gain from a change of behaviour (Belz \& Peattie, 2012; Hall, 2014). The term greenwashing has been coined to identify sustainability communication without the underlying and necessary sustainability practices (Lyon \& Maxwell, 2011; Peattie \& Crane, 2005; Smith, 1998). Greenwashing refers to overplaying the environmental performance or benefits of their products with the objective of misleading the consumer (see figure 1 and Delmas \& Cuerel Burbano, 2011). This article contributes to the sustainability marketing literature by studying greenhushing, the phenomenon of undercommunicating the sustainability practices in which a business engages (Martens, 2008). In this paper we suggest that businesses use greenhushing to mitigate a potential disconnection between their 
perception of customer expectations and their own operational position concerning sustainability issues. This paper suggests that greenhushing is not only the result of low mastery and self-efficacy in the technical aspects of sustainability communication, but is also a conscious effort to reduce any dissonance that exists between the values of sustainability held by a business and its customers.

Figure 1. A typology of firms based on environmental performance and communication

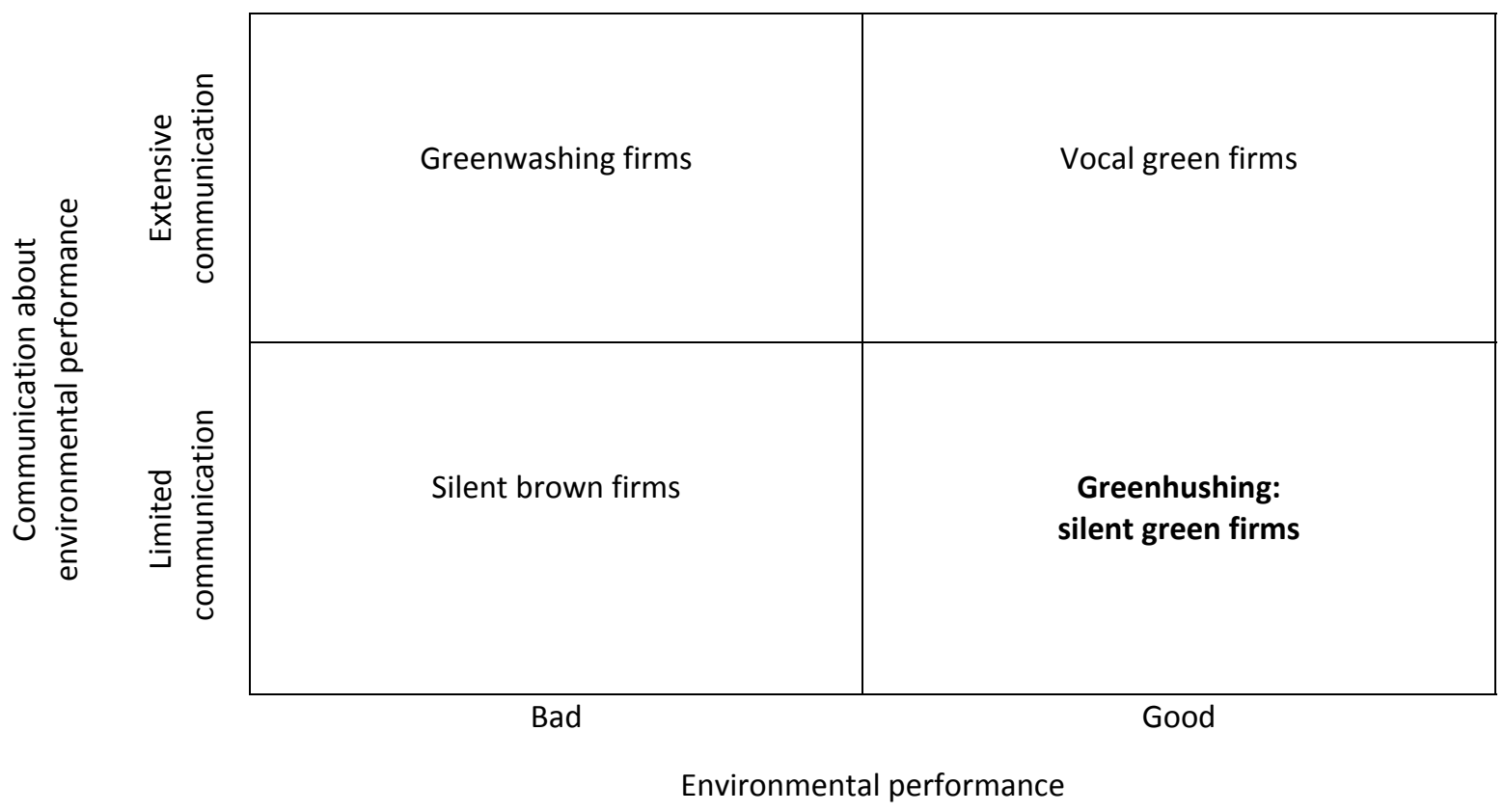

(Source: adapted from Delmas \& Cuerel Burbano, 2011)

Most studies take an instrumental view of corporate social responsibility as a management tool to achieve business goals. This is informed by a pragmatic role of transmitting information relating to sustainability communication to achieve these goals. However there is a deeper layer of meaning in that communication that is constitutive, as the communication itself represents sustainability problems as symbolic action (Bourdieu, 2012; Burke, 1966), i.e. as language that orients us to seeing things in a certain way. Situations are presented as meaningful by the way they bring certain elements to the fore, whilst pushing some to the back, and completely removing others. A further contribution to the literature from this article comes from understanding how organisations are shaped through their sustainability communication. The Communication Constitutes Organisations (CCO) approach redefines the sphere of study by stating that, by constituting and organising reality (Schoeneborn \& Trittin, 2013), communication becomes central to the enactment of taking responsibility for being sustainable. Communication not only tells us about the values of organisations, such as what businesses think their responsibilities are and the public expectations they believe are placed on them, but more importantly, it has a role in creating such values.

Sustainability makes sense through communication because an aspect of the organisational discourse, that which constitutes it as an environmentally conscious organisation, reaches beyond the words it uses (its language) to encompass the practices in which the business is engaged and the organisational structures through which it operates. Our paper considers how the problem of sustainability is framed in communication, for it is through such discursive frames that society organises itself (see Foucault, 2002). How problems are framed establishes what counts as an acceptable solution; communication shapes the social interpretation of sustainability. To the best of 
our knowledge the perspective put forward in this paper diverges from all previous tourism and hospitality articles on sustainability communication, which have, predominantly, taken a more instrumental approach.

This study investigates the language of sustainability in public moralisation, in two contexts, communication towards sustainability experts via audited accounts compared with communication towards target customers via businesses' websites, contextualised through interviews with company owners/managers (see Kreps \& Monin, 2011). Dissonant, and potentially contradictory, communicative practices tell us about the sustainability identity discourse of the businesses (Schoeneborn \& Trittin, 2013). Consideration of how businesses write about sustainability can help us to understand the meaning and significance given to the term by the message producers, whilst also indicating what they expect, or consider acceptable, as a response. We will study the rhetoric of sustainability communication used by businesses to understand the discourse(s) in which the information producers are participating. This will be done through a comparison of how the businesses involved in this research have presented their sustainability communication both to their customers and within their Environment Quality Mark (EQM) audit. The comparison will consider if they discuss environmental issues in both contexts and the language they use to do that. Such a lens allows us to study the purposeful and consequential efforts employed to influence the attitudes and behaviour of consumers through sustainability communication, as exemplified in businesses' websites, when compared to their audited sustainability reports. The focus is, therefore, on how sustainability communication both constitutes and articulates the identity of the business through the language used. The research employs interviews with the owners/managers of small rural tourism businesses.

The article is structured as follows. First we review some practical approaches to understanding the persuasiveness of sustainability communications. Then, we reflect on the meaning behind the language used in communication as a tool to constitute organisations, which leads us to understand the organisations behind the communication. We then outline the two stage sequential mixed methods approach used in this study, comparing communication in two different contexts with different audiences: sustainability audits and the businesses' websites. The results evidence how these businesses underplay and realign their sustainability efforts to fit with what they perceive their customers' perceptions to be; we reflect on how this practice shapes the businesses' views of themselves and informs their motivations for acting sustainably as a consequence.

\section{THE PRACTICE OF SUSTAINABILITY COMMUNICATION}

Businesses use their websites, and other forms of communication, to persuade their target audiences to change their behaviour. The literature so far suggests that current sustainability messages have limited persuasiveness because businesses lack the technical competence to write more persuasively (Gössling \& Buckley, 2014; Villarino \& Font, 2015). The following paragraphs discuss four criteria of messages that have each been found to influence consumer behaviour, yet we argue there is a deeper level of analysis needed to draw conclusions on the reasons why businesses communicate in the way that they do. Our findings suggest that the willingness of an individual, or organisation, to communicate a message will reflect the communicator's interpretation of how the audience will perceive that message.

The first criteria for consideration is whether a business chooses to communicate sustainability explicitly or implicitly. It is the difference between a tourism business promoting local food because it reduces food miles (explicitly referring to sustainability), or because you can trust the origin of where it came from (where sustainability is implicit). Businesses will communicate explicitly either because 
it is believed to have a direct, and positive, bearing on the company image that they try to convey, or for the education of its customers; though the latter intention carries a high risk of appearing patronising. While earlier market research suggests there is a market for sustainable tourism products (Mintel, 2007), the communication/behaviour gap (Hall, 2014) suggests customers diffuse responsibility and select products based on selfish attributes (Hindley \& Font, 2014). Tourists hold more positive, pro-environmental views of themselves than others: they adopt a mental strategy that allows them to partake in travel while diffusing responsibility and ignoring calls for behaviour change (Doran \& Larsen, 2014). Because tourism is not thought of as a harmful activity by the public in general, businesses may prefer not to communicate messages that may raise negative concerns (Jones, 1991; Kong \& Zhang, 2014). In addition, customers are generally cynical about sustainability messages (Brønn \& Vrioni, 2001; Chan, 2013), which can dis-incentivise businesses from explicitly communicating their sustainability achievements. Therefore businesses may choose to downplay their sustainability messages and make them implicit, while highlighting other benefits believed to be salient to the customer (Rettie, Burchell, \& Barnham, 2014).

Second, where businesses choose to incorporate sustainability messages in their website content they have a choice of using affective or rational language to describe their actions. Customers, particularly environmentally concerned individuals (do Paço \& Reis, 2012), are more sceptical than many hotel managers think with regard to affective green hotel claims (Chan, 2013). Businesses feel confident presenting rational, factual evidence and third party endorsements (Lowry, Roberts, \& Higbee, 2007) and this approach has been found in customer surveys to lead to more positive attitudes, and greater visit intention, than affective communication (Kim \& Kim, 2014). This provides evidence that sustainability communication that is perceived to be objective can help address potential consumer scepticism (Alexander, 2010). Moreover, it is easier for a company to display its participation in a wider credible programme, such as a certification programme or awards, than to risk the affective impact of consumers misinterpreting a message. Yet the results from opinion surveys are not translated into actual behaviour in quasi-experiments (Reiser \& Simmons, 2005). For example, in a study of sustainability communication in holiday brochure design, all customers preferred messages with affective content, and only those customers with greater sustainability experience showed interest in rational messages (Wehrli et al., 2014). There is evidence that sustainable tourism is less virtuous and more hedonic than first anticipated, requiring businesses to emphasise the emotive aspects of experiential consumption (Malone, McCabe, \& Smith, 2014).

Third, customers are more likely to respond positively to sustainability messages that refer to sustainability practices that they can experience. It is well known that how a message is framed impacts how customers respond to it (Tversky \& Kahneman, 1981). Customers respond better to positively framed messages, where the gain for the customer is emphasised, and the benefits are made clear (Kim \& Kim, 2014; Lee \& Oh, 2014). Rather than giving the appearance of moralising, sustainability practices with a clearly articulated customer benefit are better framed as enhancing quality and the customer experience (Kreps \& Monin, 2011; Malone et al., 2014). For example, a message that suggests customers should use the bus to enjoy better views of the landscape on their days out is positively framed, has an experiential benefit and hence is written for customers with lower environmental affect; while an alternative message that suggests customers should use the bus because otherwise their car will pollute the environment is negatively framed, does not emphasise a customer benefit and is therefore written for consumers with a high environmental affect. Customers with higher environmental affect have been shown to respond better to messages that convey an 
altruistic environmental benefit, although the majority of customers, with lower environmental affect, respond better when the added value is more personal (Grimmer \& Woolley, 2014).

Our fourth and final criteria relates to the active/passive dimension of sustainability messages. Cialdini and Goldstein (2004) found that where a message producer believes a customer will gain a positive experience from participation, the message will support customer empowerment to actively choose to participate. In contrast, if it is thought that the customer will not gain a positive experience from participation, the business may communicate passively (by showing the actions taken on behalf of the customer). Fundamentally, as holidaymaking is not perceived as causing environmental harm (Kong \& Zhang, 2014) a company is less likely to make salient aspects of sustainability that reduce customer enjoyment, or create a feeling of moral guilt, nor to exacerbate these by asking the customer to participate. For example, a restaurant may communicate the sourcing of its food as organic or local because this does not require customers to change their behaviour, but may choose not to add the carbon footprint of their different dishes because it arguably forces customers into a moral dilemma without adding to the customer experience. Prothero, McDonagh, and Dobscha (2010) argued that the public perception of tourism's neutral impact is an aspect of a dominant social paradigm that places humanity in a dominant position over nature. However, recent initiatives, they argue, are increasing awareness of the negative implications of the dominant social paradigm. With a growing population of people seeking greener tourism there may be increased pressure to articulate the active dimension in sustainability messages. Whilst we were not able to find any research that has investigated that possible tension within small businesses, the depoliticisation of environmental responsibility, i.e. construing environmental concern as an individualised responsibility rather than a corporate or state responsibility, has been explored by Maniates (2001) and by Connolly and Prothero (2008). These studies examined green aware consumers and their relevance for understanding sustainability messages in the context of this study is unclear.

\section{SUSTAINABILITY COMMUNICATION CONSTITUTES THE ORGANISATION}

In completing this study we could have used other criteria beyond the four dichotomies discussed above (explicit vs implicit, affective vs rational, high vs low experience and active vs passive). However, we believe these are sufficient, since our intention here is not to examine the copy writing skills of organisations, but to consider what these communication practices tell us about the values of the businesses themselves, by characterising the link between message producers and receivers. Following Giddens (2013), we can interpret that relationship as structurational; that is to say, messages are not simply the bearers of information to be communicated, they also reflect how its producer thinks the receiver will perceive them. To use Goffman's terms $(1990,2005)$, such reflexive behaviour frames the communication by placing certain information in the front region i.e. that area where the message producer (as its performer) foregrounds that which they feel is most salient to the recipient. For example, message producers that believe it is a lack of sustainability awareness that limits behaviour change may simply increase the amount of information their communications contain.

As a consequence these message producers need not necessarily communicate an attitude that is in line with their own behaviour; they are more likely to communicate messages that they believe are the ones that will present them in the best light to the recipient. With regard to messages around environmental concerns, there is extensive evidence for a gap between communicated attitude and actual behaviour (Kollmuss \& Agyeman, 2002). There are, therefore, solid grounds for arguing that a 
study of the sustainability language would be of value. The language used by an organisation has a rhetorical impact; it frames an interpretation of how the organisation is connected to the world. The language used contributes to the construction of the reader's concept of that organisation by attributing a range of meanings to that organisation.

All business communication has a rhetorical purpose then it tells us something about the way a company chooses to portray itself. The language used in sustainability communication is discursively reflexive; that is, it reveals how the business construes the values of its anticipated message receiver through the way it attempts to frame that recipient's perception of the business. It is in that space, opened up by the reflexivity of the communication between message producer and message consumer, that the question of greenwashing and greenhushing emerges. According to Alexander (2010), the main purpose of political and public environmental language is distortion, not communication, and the role of the environmentally conscious critical linguist is to understand the misrepresentation of language: most commonly understood as greenwashing. The converse, greenhushing, has not been investigated.

Alexander's arguments focus on how green consumers act in a dominant social paradigm that frames environmentally conscious consumption as the wise use of natural resources for economic growth, achieved through free markets (Kilbourne, 2004). According to Alexander (2010), the discourse of market economics is appropriating, and narrowly framing, the discourse of sustainability. Within the discourse of the free market, the rhetoric of green consumerism argues that purchasing green products can help the planet. This individuated consumer identity creates the impression that consumers are empowered to change society with their wallets (Cox, 2012; Smith, 1998). Such discourse has led scholars to develop models and theories, under an umbrella of "sustainable development", in which ecological and environmental factors are understood to be crucial to overall socio-economic progress (Haque, 2000). Sustainability discourse thus involves communication that interlinks a dominant economic framework with environmental and social issues. While an exploration of three strands of that discourse (economy, environment and society) can help to orientate tourism development towards more sustainable approaches, the dominant paradigm in the discourse of sustainable tourism development is still focused on the economic benefits over those to society and the environment, and that distortion obscures the necessity of exploring, in more depth, discourses of sustainability (Elgammal \& Jones, 2007; Haque, 2000; Reed, 2013).

In keeping with Alexander's analysis, if tourism businesses are seeking to target green consumers we would expect them to constitute themselves through a sustainability discourse. A business that felt comfortable with their sustainability practices would show little difference in the way they communicate those practices in voluntary sustainability audits and the messages they produce for their customers. If the businesses are communicating more to customers than they are delivering in practice then it can be argued they are engaging in a practice of greenwashing. However, if it is found that they are communicating less it would suggest they are practicing some form of greenhushing. If businesses are engaging in more sustainability practices than they use to constitute themselves through their customer facing communication, it does raise questions concerning what other forms of discourse they are using to constitute themselves.

\section{METHODOLOGY}

We restate that the purpose of this study is to understand the relation between the sustainability practices of tourism businesses and their customer facing communication. The rationale for doing this is to better understand how the businesses constitute their identities through communication. We 
used a mixed methods sequential design with four interrelated stages: 1) Scope definition: refining the scope to identify suitable data from a sustainability audit that could be used in the second stage; 2) Data coding: coding and statistical analysis of text data from the audit and website to identify patterns of convergence or divergence in the discourses employed; 3) Language assessment: observation of the frequency, and common association, of words used during interviews; and 4) Discourse analysis: an analysis of the interviews held with business owners/managers. The first two stages resemble previous research on greenwashing that compares facts (Bonilla, Font, \& Pacheco, 2014; Clarkson, Li, Richardson, \& Vasvari, 2008), while the latter two stages follow an interpretative approach common in communication (Alexander, 2010; Baxter \& Babbie, 2004). This combination of methods may feel uneasy to some researchers, as only $12 \%$ (or 56 ) of the 468 sustainable tourism articles published in JOST over ten years have used mixed methods and, of those, only 10 articles adopted an equivalent weighting between the quantitative and qualitative parts (Molina-Azorín \& Font, 2015).

Our research took place in the Peak District, which was the first national park to be designated in England in 1951 and covers 1,437 sq kilometres. 2014 data shows the Peak District to be the third most visited national park in England, with 8.75 million visitors per year, 16\% of which are overnight visitors (National Parks UK, 2015; PDNPA, 2014). There is a long tradition of tourism business networks established for the purpose of public-private partnerships in the Peak District National Park, although many businesses perceive the relation between the Park Authority and themselves as ineffective (Saxena, 2005). As part of efforts to get businesses to take more ownership for the protection of the park, in 2001 the Peak District National Park Authority established a certification programme called the Environmental Quality Mark (EQM). This was initially subsidised by the park authority but, due to the economic recession cutting park budgets, is now operated under license by a team of qualified and experienced environmental auditors.

Our sampling frame is the 31 accommodation businesses in the Peak District National Park certified by EQM in 2014. The number of certified businesses was much greater when the National Park Authority subsidised certification and provided additional learning benefits, but, since the government budget cuts, the certification process is now paid for by the award holders, and the number of participating businesses has reduced. The businesses that are still accredited generally fall under the group that Saxena (2005) would have classified as enthusiasts or activists, where EQM membership is part of their identity or there is a loyalty to the EQM staff for the help they have provided. These businesses are all small, rural tourism businesses, often farm diversifications offering bed and breakfast or self-catering cottages and, less often, full hotel services. Examples of businesses interviewed include Wheeldon Trees Farm (nine self-catering cottages sleeping 30 people in total), Fernyford Barn (converted barn in a working farm sleeping four), Hoe Grange Holidays (four 2bedroomed cabins specialising in wheelchair access), the fine dining country hotel Fischer's Baslow Hall and the 23 bedroom, 4 star Losehill House Hotel.

In order to analyse the discourse of actual sustainability practices undertaken, we used the EQM audit trail of these 31 businesses. To apply for EQM status the businesses are required to complete an online form that requires them to outline their practices, in their own words, for a range of assessment criteria. Those criteria include indicators of explicit environmental practice (e.g. how do you manage your energy, water, waste and so forth?) but with a customer journey angle, enabling the businesses to consider each step with respect to their customer engagement. Examples include "In your marketing and promotional activities, how do you show potential customers and visitors what you are doing and how the Peak District is special?", "How do you show customers what you are doing to reduce your environmental impact?" and "How do you reduce the negative impact of your cleaning 
processes? How does the customer know?". It is important to note that in the EQM audit itself there is an emphasis on how sustainability actions are communicated to customers; this is less common in other certification programmes, and a primary reason why this research has chosen to study EQM certified businesses. The certification process is robust: qualified auditors review the application, conduct a verification visit and write a report. The application is then assessed by an independent Award Panel, who judge if the business meets the requirements of the EQM scheme. We therefore take the statements provided in the audits to be an accurate representation of what the 31 businesses do, to the extent that any audit can ensure this.

We tabulated 1389 statements from the 31 sustainability audits of these businesses (average 45 statements per business, ranging from 21 to 95). Those statements were then coded, using a modified coding system previously used in categorising corporate social reports (Bonilla et al., 2014; Clarkson et al., 2008), that considered: a) the relevance of the statement to the criteria; b) whether the action taken was soft or hard (which refers to how easy it is to make a claim without much effort); c) whether the actions taken were environmental, social and/or economic (multiple responses being allowed); and d) whether the actions would be altruistic (benefiting the society and the environment), or would have benefits for the business, and/or the customer (again with multiple responses permitted). We chose to use dichotomous variables to simplify the analysis, except for the variable that tested how relevant the sustainability practice reported was to the audit criteria, where we felt greater level of scrutiny was needed and used a 0 to 5 scoring system. So, for example, a business providing not only extensive detail but also meaningful actions, in response to the question posed, would get a high score. One business scored 5 out of 5 in sustainability marketing by stating that: 1) We have a Green Policy on our web site and it mentions local food purchasing and our support of Friends of the Peak District; 2) Our leaflet is printed on recycled paper and has the EQM logo on; 3) We advertise on www.responsibletravel.com and www.greentraveller.com; 4 ) We have a section on our website about getting to us by public transport; and 5) We offer a $5 \%$ discount plus a complimentary breakfast basket to guests arriving without a car, and we offer to refund any bus travel on our local 442 bus. A different business scored a 2 out of 5 for responding: 1) We have an environmental policy on the cottage website; 2) Leaflets and brochures show the EQM logo and we are pleased to promote this verbally; and 3) We promote leaving the vehicle and using local shops and pubs by walking from the door. We checked for cross-coder reliability by coding some entries together, then coding independently and checking cross-coder agreement; also by having regular meetings to check flagged statements.

Our analysis continued by checking whether the statements on the audit were communicated on the websites of these 31 businesses. Our analysis focused on the articulation of discourse through text. Whilst we are fully aware of the semiotic importance of visual and non-textual media, particular for website marketing, it was felt that the inclusion of too many paralinguistic features would make the analysis too large for a single journal article. However, eight separate checks were included as follows. We checked on the location of sustainability messages to see: i) whether they were on the homepage or, if not, how many clicks it took to reach them; and ii) if those messages were located on a dedicated sustainability page. We also checked for consistency between messages in the audit and website for: iii) soft or hard sustainability claims (referring to how easy these are to claim without actual evidence of practising); and iv) whether their emphasis was environmental, social and/or economic emphasis. We coded web messages using four persuasiveness criteria used by Villarino and Font (2015) (as outlined earlier in the literature review) and, in doing this, we checked if the messages were: v) explicit or implicit in speaking about sustainability; vi) using affective or rational language to 
justify their actions; vii) outlining sustainability actions conducive to be experienced by customers or not; and viii) allowing customers to actively or passively participate in these sustainability actions.

In order to triangulate any findings from the audit and web texts analysis, we conducted a series of semi-structured interviews. 27 of the 31 businesses were contacted; 11 businesses accepted, from which we scheduled eight interviews. Purposive sampling meant we selected businesses with different levels of thoroughness in their sustainability audits. Each interview lasted 75-90 minutes and was recorded, transcribed and analysed for evidence of articulating sustainability messages, to better assess the relationship between sustainability practices and communications (Miles \& Huberman, 1994). The discourse analysis in this paper went from a general understanding of the written data to understanding the scope of the underlying motivation behind the way companies communicate sustainability (Taylor \& Bogdan, 1998). We reviewed the transcripts a number of times, searching for construct ideas and patterns, then focused on bridging the transcripts with the reduced early stage of quantitative data analysis in order to come up with more robust codes. While previous literature has highlighted the use of codes and categories as a fundamental part of undertaking discourse analysis, such discussions have tended to focus on qualitative data; rather than a mix of qualitative and quantitative data. The challenge was to develop higher level codes that bridged qualitative and quantitative data; moving from a descriptive to an interpretive level of data analysis (Punch, 2013). Categories were developed that could help us make sense of the data and facilitate the analytical thinking of the researcher (Maxwell, 2012).

Finally, the language used by those businesses that participated in the interviews was compared with that used in their completion of the EQM audit. Pustejovsky, Anick, and Bergler (1993) suggest word choice (sometimes referred to as lexical preference) in communication plays an important role in how the communicator constructs their identity for a given audience. Bybee and Hopper (2001) and Yaeger-Dror, Granadillo, Takano, and Hall-Lew (2010) have indicated that it is important to consider how language is used because it provides an insight into the world view of the language user. Wengao (2009) and Hyland (2010) go further and argue that such lexical preferences are also indicative of the users' sense of self-identity.

\section{RESULTS AND DISCUSSION}

We find ample evidence of reflexive behaviour in the audit, website and interview data; this suggests that, when it comes to sustainability practices, the businesses are doing more than they are communicating to their customers. Adopting a CCO approach suggests that one aspect of how these businesses are constituted is through the different framing of their communications around issues of sustainability; the discourse(s) in which they are participating being indicated by what the owners/managers of those businesses choose to put into the front region i.e. foregrounding what they construe as most salient to the message recipient. We first analyse how these businesses communicate their sustainability practices to legitimise their clients' rights as consumers, which in turn allows us to consider how the organisations themselves are constituted through communicating their organisational identity.

These businesses legitimise that customers consume the landscape through the sustainability actions the businesses takes on their behalf, generally without being noticed by their customers. A business's environmental language aims to provide reassurance to its clients (Alexander, 2010) with the emphasis being on how the business works in the background to maintain the tourists' playground. In doing so, the business legitimises the tourists' use of the resource through a language of shared values i.e. an appreciation of the value of nature. This is evidenced by: i) the fact that only $30 \%$ of 
sustainability practices found in the audits are communicated in the websites; ii) the different tone of communication between the audits and the websites; and iii) the way these businesses explain their behaviour in the interviews, as outlined below.

The businesses select which messages to communicate according to their perception of the audience's expectations of them. We find that of the 1,389 statements made by the 31 businesses in their sustainability audits (which were assessed for accuracy by auditors and therefore reliable) only 407 were communicated in their websites. The audited statements were primarily altruistic $(77 \%)$, showing concern for the National Park and society at large, but also showed benefit to the business itself (68\%) through eco-efficiencies and competitive advantages; the statements showed less concern for customer benefits (50\%). In contrast, the messages displayed in their websites had a drop of $7 \%$ in altruism, but an increase of $4 \%$ in business benefits and, most significantly, a $15 \%$ increase in customer benefits. DePoe (1991, in Cox, 2012) suggests that there are three basic frames for green product advertising, these use nature as: i) - a backdrop i.e. promoting consumption in a natural setting; ii) a product i.e. promoting the consumption of nature; and iii) an outcome i.e. communicating the benefits to nature as a result of the business's actions. In our inquiry we found evidence of all three frames, although nature as an outcome was far less evident in the websites than in the audits. The fact that businesses wrote messages based on customers' expectations shows a clear understanding of how to reframe the benefits of a message and how to select messages according to their relevance, with the outcome being moral framing in the altruistic benefits and pragmatic framing in both the business and customer benefits (Kreps \& Monin, 2011). We exemplify this with examples from their websites. The following is an example of a message that carries benefits for society and/or the environment (enhancing the space) and the customer (enjoying the improved space):

"By improving the exterior of our property we have helped to improve the look of the village and having started a holiday cottage business, we contribute to the local economy of Litton, as our guests spend considerable sums in the local shops and pub."

This comes across differently to the following example of a message that carries benefits for society and/or the environment (benefits the EQM members through networking and sharing knowledge) and the business (receives new ideas):

"We network with other EQM businesses at EQM events and via email to find out the best suppliers for our business".

Equally, this final example carries benefits specifically for the business:

"We ask for guests' comments and ideas on how we could improve our green credentials".

The practice of tailoring messages to perceived audience needs is evident from the analysis of the communication persuasiveness of website messages. Much of the text is explicit about sustainability practices (67\%), for example, the statement "We provide you with eco washing up liquids, etc" shows the business cares about the environment because the "eco" prefix was used but the initiative does not compromise on the customer experience. There are, however, many other examples of implicit text that offer information attractive to all customers regardless of how environmentally conscious they are, for example "Walks for all abilities are accessible directly from the front door of the cottages"; in this example, the implicit message is to reduce pollution from using transportation. 
Most of the text is written in affective language (78\%) such as "we would like to support visitors choosing to use public transport as much as possible", rather than rational language (22\%) such as "Most of the cleaning materials are bought in bulk once every three months" and "Outside lights are fitted with infrared sensors". The emphasis on the website is on promoting the experiential benefits (86\%), for example "We use home produced and locally sourced products where possible" where arguably customers gain a personal experience of the destination visited, with fewer cases of nonexperiential messages such as "...in keeping with our efforts to reduce our carbon footprint as much as possible", which the client is unlikely to experience. In general, the messages promote active engagement on the part of the clients (85\%), for example "Come and enjoy the best of British design from locally made furniture to English fine furnishings". Where framing messages with a more personal tone and emphasising customer benefit is evident, this suggests that the businesses are targeting individuals with lower environmental affect (Grimmer \& Woolley, 2012) because they do not wish to be constituted as preaching to their customers (Kim \& Kim, 2013; Stanford, 2014).

The composition of the sustainability messages in the audits and websites is also very different, and suggests that the businesses expect their customers to be seeking to engage with pristine nature. As part of complying with an idealised view of rurality, the businesses remove human agency from their messages, which alters the balance of their triple bottom line. The EQM audits provide the opportunity for open ended answers regarding how the business meets different generic sustainability requirements, without leading for a particular aspect of the triple bottom line. In the audits, the businesses refer to more social actions (68\%) than environmental (57\%), in contrast to their websites where activities with an environmental focus were communicated $17 \%$ more often, but social actions were communicated $12 \%$ less often. In addition, $55 \%$ of the actions with a benefit to the customer, reported in the audit, had an environmental focus vs the $44 \%$ that did not have a customer benefit, and yet only $47 \%$ of actions written as benefiting customers had a social content, vs $57 \%$ that did not.

The rhetoric's constitutive role for EQM businesses shows how the environment is framed positively not negatively i.e. not as a problem. We find the businesses distance themselves, and shelter their customers, from the negative externalities of the tourists' enjoyment. Deletion of agency, by using a generalised agent, is a well-rehearsed technique to diffuse responsibility (Alexander, 2010). Consequently, implicit messages couched sustainability practices in broader quality arguments, portraying it as an aspect of normality (Rettie, Burchell, \& Barnham, 2014); this was most clearly seen in the language used in expressing active versus passive messages. The active messages, which are more direct, compel the customer to do something (O'Keefe, 2002), and are positively framed as an immediate benefit to the destination (e.g. recycling to keep the Peak District clean). Passive messages, however, are used to communicate the less palatable sustainability requirements, i.e. those hindering the customer experience such as "environmentally friendly cleaning products are used" which the interviewees mentioned customers believe clean less thoroughly. These passive messages obfuscate responsibility by deleting the agent (Alexander, 2010) and reducing the likelihood of the customer feeling guilt (Kong \& Zhang, 2012).

The purposeful positive framing of sustainability messages is best exemplified in messages pertaining to the carbon footprint of transport or the sourcing of building materials, where such factors cause a high negative impact but are necessary. During one of the interviews, a business stated that because "...our guests are paying a lot of money, we cannot restrict their stay by asking them to practice sustainability. Carbon footprint is one example of the things that we do not communicate", which shows that when sustainability is inconvenient, businesses tended to deflect attention and 
downplay real issues (Alexander, 2010). For example, despite most of the businesses in this study being farm diversifications, only one of them speaks of the environmental impacts of methane from cow farming (using humour and drawings in an effort to make the issue more accessible). Humour is often used to communicate sustainability messages when an organisation feels uncomfortable about how a message could be received. It is particularly meaningful that none of the businesses demonstrate on their website, or mentioned during their interviews, that they purposefully aim to attract domestic tourists in order to reduce the potential carbon footprint they cause. Conversely, some interviewees suggested that attracting international customers is a sign of pride in the quality of their business. The fact that they do not place a high value on this important factor is because of perceived causal distance i.e. they do not feel that the impacts of transport to the destination are attributable to them (Jones, 1991; Kreps \& Monin, 2011), in the same way that they consider it would be inconvenient to acknowledge certain impacts, where these might make their customers feel uncomfortable.

Our findings show that the businesses normalise sustainability practices to remove customer guilt. Normalisation enables them to construct a narrative of agency, causality and responsibility that is reassuring (Fairclough, 1992). 31\% of the businesses' sustainability messages are communicated within specific sustainability pages on their websites and these are more explicit, rational, nonexperiential and focused on altruistic benefits than their other messages. The $69 \%$ of messages found elsewhere in their websites are more implicit, emotional, experiential and customer focused, suggesting a normalisation of green messages and integration into the broader communications that constitute the organisation (Grant, 2007; Schoeneborn \& Trittin, 2013). As such, it is consistent with other forms of describing quality; we do not expect to find separate tabs for all quality marks, rather they are suggested by their integration throughout the organisation's website. By normalising, the business is allowed to use euphemisms in relation to the environment and therefore avoid having to moralise (Tenbrunsel \& Messick, 2004). Businesses present an idealised view of rurality that avoids conflict for the customer (Urry, 1990); their intention is to make green look normal and showing rurality simply as an alternative to daily, urban life. This is notably different to greenwashing, which suggests that normal business practices are done specifically for sustainability reasons (Grant, 2007).

Along with the normalisation, we find that businesses increase the salience of positive actions to articulate sustainability practices. For example "local" sourcing, which is used to refer to the sourcing of supplies, labour and other resources, appears 367 times in the audit statements, whereas the adjectives environment, social or economic, collectively, appear just 63 times. A further example is discernible in the lack of references to climate change in all three sources - the audits, the websites and the interviews. There is only one explicit entry in the audit statements "...our booking form invites guests to donate to climate change". Only one of the 31 businesses refers to climate change on their website, while others suggest car free holidays or days out without explicit reference to carbon emissions or climate change. The effort that has gone into providing car free holidays is in some cases remarkable- offering equipment for pets and babies, a food store, breakfast baskets, electric bikes, useful information on things to do from the doorstep and, of course, details on how to get to the site by public transport, all of which shows a real commitment to sustainability. Evidence from the interviews and the websites shows no mention of climate change or global warming. By framing sustainability as a normalised local practice the business is able to frame potential areas of customer guilt as a positive message; constituting the organisation as one that offers solutions rather than raises problems. Consequently, walking and recycling appear regularly without mention of the 
environmental contribution these make; this is in keeping with previous evidence that customers prefer positively framed (Lee \& Oh, 2014), appealing sustainability messages (Wehrli et al., 2014).

In addition, we find that businesses tend to communicate soft, palatable actions that do not challenge the presentation of an idealised rurality to customers. This is evident in the different tones used in the audit statements and the communications when describing actions. For example, we find that actions reported as soft (easy to achieve) in the EQM reports are communicated $12 \%$ more often on the website than in the reports. The hard actions reported in the EQM are data driven facts of interest to an environmental auditor (e.g. the results of a biodiversity survey or efficiency of solar panels), whereas the soft actions are often vague statements about caring for the countryside. Only in a few cases do we see examples of soft actions in the EQM reports (such as the sourcing of food from local suppliers "whenever possible") also being marketed on the businesses' websites as hard, concrete actions, for example dedicating space to "our local food heroes", naming suppliers and praising the quality of their produce. The examples occur when the hard evidence provides customer reassurance and, therefore, the practice communicates a positive customer experience.

Messages of holidays as escapism are reinforced on the websites and in the interviews; the emphasis is placed on customers creating social bonds to remove a sense of misplacement. As gatekeepers of the tourism experience, the businesses comply with the dominant social paradigm expectation that the countryside is a playground. We see the altruistic aspects of sustainability played down and the quality aspects highlighted. So, for example, in messages that promote walks from the accommodation's doorstep, both an altruistic (reduction in $\mathrm{CO}_{2}$ ) and a consumer (convenience) benefit are emphasised, although, the EQM reports tend to focus on the former and the websites on the latter. Some of the businesses suggest that their guests are not concerned about how green their holiday is. For example, one business declares "I am happy to try new sustainability practices but not happy to publish it in my website, because not many people try to look for green holidays". Given that perspective, it is unsurprising that some organisations feel it is unnecessary to communicate sustainability practices. Other interviewees suggested that storytelling is a better fit for the ethos of their sustainability communication; it is seen as more coherent with a construal of holidays as an escape.

In summary, we find that the sustainability communication of these businesses reflects current society values (Holbrook, 1987), as they choose to not communicate many of their more onerous practices in fear that this will be met with disapproval, for holidaymakers have a sense of entitlement and lack the financial incentives to save resources(Miller, Rathouse, Scarles, Holmes, \& Tribe, 2010). Instead, the businesses use choice architecture and nudging (Hall, 2014), to provide more sustainable consumption opportunities as normal (Grant, 2007) within the context of the meaning of rural holidays. Environmentally friendly practices take place in the background, which guarantees a less negative impact without having to bother the guests, while communication is reserved to "choice edited", positively perceived actions such as the selection of local suppliers to reinforce breakfast quality and the promotion of walks from the doorstep as a convenience.

We interpret these findings by suggesting that the majority of businesses interviewed are using EQM as a symbolic legitimacy boundary, a form of belonging that provides reassurance that their presence in the landscape, and local society, is justifiable. Many businesses generate narratives around their connection to the locality over specific sustainability actions and corporate responsibility 
initiatives. We find evidence in keeping with the corporate social disclosure literature that suggests that moral intensity and business salience increase the pressure to legitimise (Al-Tuwaijri, Christensen, \& Hughes, 2004; Deegan, 2002; Jones, 1991). While we cannot discern a statistical difference between sustainability messages and the size or age of the business, the connection between communicating sustainability actions and organisational identity is clearly discernible for interviewees who are not originally from the Peak District, for whom EQM serves as a mark that they are doing their bit to look after the location. One business stated "We were living in the city before moving here. We go to courses and workshops to learn about sustainability. We are consistent in doing things according to the EQM guidelines...we do our best to help the local community". Some business owners/ managers still refer to themselves as "non-local" even when they have spent decades in the area.

Further evidence of reporting that arises from business salience comes from the connection between accommodation category and the level of sustainability communication: five star businesses communicate $40 \%$ of their actions, four star businesses $27 \%$, and three star only $12 \%$. The gap between audited and communicated practices can act as an indicator of how the organisation constitutes its identity through communication. Higher accommodation category businesses, and those owner/managers who are incomers to the locality, seem more comfortable with articulating their identity as custodians of place, while other businesses and owner/managers seem more inclined to identify themselves as of the place, separating out their practice from what they communicate. Higher accommodation category businesses, in particular, report sustainability actions that suggest they are trying to make a difference to their local fabric. The actions communicated by higher category businesses in the interviews were often framed as making a contribution to local social wellbeing, not simply in environmental or economic terms. Interviewees, for example, spoke of promoting local areas and walks (Businesses 2 and 4), employing local staff (Businesses 3 and 6), sourcing milk from local suppliers (Business 2), encouraging customers to try locally produced and distributed food, value it (Business 7) and, though it may be more expensive, buy it (Business 4).

Some interviewed owners/managers, particularly those with businesses in the lower accommodation categories, suggest that they use the EQM mark purely as a signifier of their organisational identity i.e. to reduce the dissonance between their values and the need to be commercial; in these cases, having the EQM accreditation is more for the business than for the customers. This finding is consistent with Kreps and Monin (2011) who argue that presenting sustainability actions as an essentially altruistic public good can project an image of lower organisational competence, reduce likability by sounding worthy, and increase vulnerability to seeming hypocritical. This is a point echoed by some interviewees who expressed their concerns around customers perceiving a trade-off between quality and sustainability. Reiser and Simmons (2005) also found in their research that consumers saw eco-labelling information of tourism services as irrelevant and ignored an entire section of a marketing display in a tourist office. They concluded that seeking environmentally friendly information is affective and not cognitive. In our study, while the businesses show interest in practicing sustainability, there is a suggestion that some of them sense an incompatibility between identifying themselves as a quality business and as an overtly green one. An example of that perspective was expressed by the owner of Business 2, who argues that "Customers do not bother about the environment when they are in a holiday ...'5-stars' is better than 'green'; 'quality' is better than 'eco'... no one is looking at it". Business 4 supports Business 2's position by asserting "We cannot communicate much about sustainability practices because that might put guests off" and others agree that a heavy environmental message on their website would deter 
customers. Generally, the businesses told us they find little economic gain from communicating sustainability, which in turn means that they choose to communicate far less than they actually do. Furthermore, what they do communicate is done for their own, rather than their customers', satisfaction as they believe customers do not pay attention to it anyway.

\section{CONCLUSIONS}

The businesses under investigation not only do more than they state they are doing but also they describe what they do differently in different contexts. This finding resulted from a review of 31 sustainability certified business, using information obtained from completed EQM audits and from the websites of the businesses as source data. We find that only $30 \%$ of sustainability practices are communicated in the websites, with a greater consumer focus than in the audits but still with an altruistic and business benefit. Sustainability messages are primarily explicit, written in affective language and promote experiential benefits and active participation of the customers. The messages show an idealised view of rurality that removes human agency and diffuses responsibility, while playing down unpalatable aspects and providing reassurance to customers by emphasising the positive aspects of sustainability to support the sense of escapism from life's daily pressures. Comparing the two contexts of source data (one representing what the businesses state they do in an audit and the other being a forum through which those same businesses talk about what they do to their customers) offers us an opportunity to explore the possibility of greenhushing.

This article helps us to see how the communication of sustainability plays a part in defining organisational identity. How these businesses portray the type of product they offer explains how they represent their social identity in their websites. Following the logic of CCO, their communication also affects how these same businesses see themselves and how they influence their own perception of success and self-worth. The reasons for moral muteness have been explained for individuals in large firms as resulting from social pressures (Jones, 1991). This article suggests that the manner of communicating sustainability practices in the two contexts constitutes the organisation from the values of their owner/manager and what they perceive their customers' expectations of the organisation to be. We therefore find evidence that greenhushing is a combination of moral silence, by not talking about $70 \%$ of their actions, and moral muteness, defined as privately justifying acting primarily on moral grounds yet publicly taking a pragmatic approach (Kreps \& Monin, 2011). Both aspects of greenhushing are influenced by the low moral intensity of tourism i.e. that the owners/managers are less likely to moralise in relation to issues their target audience do not already see as subject to moral scrutiny (Jones, 1991).

We therefore argue that both greenwashing and greenhushing share the similarity of realigning business practices to our social norms. Greenhushing also contributes to the advertising industry's attempts to manipulate society's values towards consumerism through conspicuous consumption (Pollay \& Gallagher, 1990), only, in this case, it is by playing down the details of what the business does to be sustainable to a level that the customer finds acceptable to enjoy their holiday. Greenwashing, on the other hand, attempts to put the customer at ease by pretending that the business has taken care of potential customer concerns. Both are forms of green advertising that "as a marketing strategy, falls within the dominant social paradigm because its primary goal is to sell more products without regard for the limits to growth theses while shrouding itself in the cloak of social responsibility" (Kilbourne, 2004:201). 
The positive frame (sustainability = more enjoyment) used amongst our 31 businesses confirms Kilbourne's finding, but how these businesses communicate sustainability tells us about their values and, equally, the choices they make when communicating sustainability shape their own sense of identity and self-worth. A CCO approach helps us reframe the origin of greenhushing into one that asks how a business constitutes itself through its communications. We find that tourism businesses with sustainability values resent having to market themselves based on those values (Ateljevic \& Doorne, 2000; Font, Garay, \& Jones, 2014; Sampaio, Thomas, \& Font, 2012). The businesses accept, but are disappointed by, the fact that they cannot communicate more of what they do and they would like their communication to show the benefits to society of their practices and not only be written for "marketing" purposes. There is a sense of wishing that customers would have a similar level of commitment to the Peak District as they themselves do and they display resentment that sustainability's value is reduced to having only a marketing function. They acknowledge how little they can change their customers' behaviour and how this affects their own sense of achievement in being sustainable. When these businesses choose to communicate, they prefer to state what they do, and their personal reasons for doing it, rather than engage in what they consider to be sales gimmicks. The need to market their businesses reminds them of the fact that consumers do not care about the environment as much as they do, which makes them feel uneasy about their need to make a living from clients that do not share the same values.

This article provides a first entry into a wider, more encompassing, discourse for sustainability communications, going beyond earlier technical tests on the actual persuasiveness of messages (Villarino \& Font, 2015). We are aware of the fact that this study only partly explains how a business promotes its products or services, and that communication in other forms and channels should be researched. A website is only one marketing point and further communication may be available in print, on site or verbally. Further research is also needed to understand the process of, and choices behind, creating sustainability messages and both how they reflect the values of the organisation as well as how the reaction of the customers to such information shapes the values of the organisation. We are aware that the current literature suggesting that large firms practice greenwashing and small dedicated firms practice greenhushing is too crude, and a better understanding of greenhushing across cultures and organisation types is needed. Finally, it is worth studying whether or not greenhushing results from the businesses considering sustainability practices as common and therefore not worthy of communication (Lynes \& Andrachuk, 2008).

In the meantime, the lessons learned through this research will inform our team's efforts to train businesses to write more sustainability messages and to make them more compelling by better understanding the links between the messages and the people behind them. The underlying approach behind most sustainability management and marketing training is a commercial business case that does not represent how all businesses choose to engage in sustainability (Font, Garay, \& Jones, forthcoming). Through this study we understand that our businesses seek both reassurance that there are customers with the same values as themselves and need help in writing copy that will attract them, so that they can regain enjoyment in sharing the landscape with likeminded individuals and be the custodians of their national park.

\section{REFERENCES}

Al-Tuwaijri, S. A., Christensen, T. E., \& Hughes, K. (2004). The relations among environmental disclosure, environmental performance, and economic performance: a simultaneous equations approach. Accounting, Organizations and Society, 29(5-6), 447-471. 
Alexander, R. (2010). Framing discourse on the environment: A critical discourse approach. London: Routledge.

Ateljevic, J., \& Doorne, S. (2000). Staying within the fence: lifestyle entrepreneurship in tourism. Journal of Sustainable Tourism, 8(5), 378-392.

Baxter, L., \& Babbie, E. (2004). The basics of communication research. Belmont, CA: Thomson Wadsforth.

Belz, F. M., \& Peattie, K. (2012). Sustainability marketing: a global perspective (2nd ed.). Chichester: John Wiley and Sons.

Bonilla, M. J., Font, X., \& Pacheco, R. (2014). Corporate sustainability reporting index and baseline data for the cruise industry Tourism Management, 44, 149-160.

Bourdieu, P. (2012). Language and symbolic power. Cambridge: Polity.

Brønn, P. S., \& Vrioni, A. B. (2001). Corporate social responsibility and cause-related marketing: an overview. International Journal of Advertising, 20(2), 207-222.

Burke, K. (1966). Language as symbolic action: Essays on life, literature, and method. Berkeley, CA: University of California Press.

Bybee, J. L., \& Hopper, P.J. (2001). Introduction to frequency and the emergence of linguistic structure. In J.L. Bybee \& P.J. Hopper (Eds.), Frequency and the emergence of linguistic structure. Amsterdam/Philadelphia: John Benjamins, 1-24.

Chan, E. (2013). Gap analysis of green hotel marketing. International journal of contemporary hospitality management, 25(7), 1017 - 1048.

Cialdini, R. B., \& Goldstein, N. J. (2004). Social influence: Compliance and conformity. Annual. Review of Psychology, 55, 591-621.

Clarkson, P. M., Li, Y., Richardson, G. D., \& Vasvari, F. P. (2008). Revisiting the relation between environmental performance and environmental disclosure: An empirical analysis. Accounting, Organizations and Society, 33(4-5), 303-327.

Connolly, J., \& Prothero, A. (2008). Green Consumption Life-politics, risk and contradictions. Journal of Consumer Culture, 8(1), 117-145.

Cox, R. (2012). Environmental communication and the public sphere. Thousand Oaks, CA: Sage.

Deegan, C. (2002). Introduction: The legitimising effect of social and environmental disclosures-a theoretical foundation. Accounting, Auditing \& Accountability Journal, 15(3), 282-311.

Delmas, M. A., \& Cuerel Burbano, V. (2011). The drivers of greenwashing. California Management Review, 54(1), 64-87.

DePoe, S. P. (1991). Good food from the good earth: McDonald's and the commodification of the environment. Paper presented at the Proceedings of the Seventh SCA/AFA Conference on Argumentation. Argument in controversy, Annadale, VA.

do Paço, A. M. F., \& Reis, R. (2012). Factors affecting skepticism toward green advertising. Journal of Advertising, 41(4), 147-155.

Doran, R., \& Larsen, S. (2014). Are we all environmental tourists now? The role of biases in social comparison across and within tourists, and their implications. Journal of Sustainable Tourism, 22(7), 1023-1036.

Elgammal, I., \& Jones, E. (2007). Using Discourse Analysis to Explore the Achievability of Triple Bottom Line Sustainability (TBLS): The Case of the Bluestone Holiday Village. In F. Jordan, L. Kilgour \& N. Morgan (Eds.), Academic Renewal: Innovation in Leisure and Tourism Theories and Methods, Volume 2 (LSA 97). Eastbourne: Leisure Studies Association.

Font, X., Garay, L., \& Jones, S. (2014). Sustainability motivations and practices in small tourism enterprises. Journal of Cleaner Production, doi:10.1016/j.jclepro.2014.01.071.

Font, X., Garay, L., \& Jones, S. (forthcoming). A social cognitive theory of sustainability empathy. Annals of Tourism Research, in publication.

Foucault, M. (2002). The order of things: An archaeology of the human sciences. London: Routledge.

Goffman, E. (1990). The presentation of self in everyday life. London: Penguin.

Goffman, E. (2005). Interaction ritual: Essays in face to face behavior. Chigago, IL: AldineTransaction.

Gössling, S., \& Buckley, R. (2014). Carbon labels in tourism: Persuasive communication? Journal of Cleaner Production. 
Grant, J. (2007). The green marketing manifesto. Chichester: Wiley.

Grimmer, M., \& Woolley, M. (2014). Green marketing messages and consumers' purchase intentions: Promoting personal versus environmental benefits. Journal of Marketing Communications, 20(4), 231-250.

Hall, C. M. (2014). Tourism and social marketing. London: Routledge.

Haque, M. S. (2000). Environmental discourse and sustainable development: Linkages and limitations. Ethics and the Environment, 5(1), 3-21.

Hindley, A., \& Font, X. (2014). Ethics and Influences in Tourist Perceptions of Climate Change. Current Issues in Tourism, ahead of print http://dx.doi.org/10.1080/13683500.2014.946477, 1-17.

Holbrook, M. B. (1987). Mirror, mirror, on the wall, what's unfair in the reflections on advertising? The Journal of Marketing, 51(July), 95-103.

Hyland, K. (2010). Community and individuality: Performing identity in applied linguistics. Written Communication, 27(2), 159-188.

Jones, T. M. (1991). Ethical decision making by individuals in organizations: An issue-contingent model. Academy of Management Review, 16(2), 366-395.

Kilbourne, W. (2004). Sustainable communication and the dominant social paradigm: can they be integrated? Marketing Theory, 4(3), 187-208.

Kim, S.-B., \& Kim, D.-Y. (2014). The Effects of Message Framing and Source Credibility on Green Messages in Hotels. Cornell Hospitality Quarterly, 55(1), 64-75.

Kollmuss, A., \& Agyeman, J. (2002). Mind the gap: why do people act environmentally and what are the barriers to pro-environmental behavior? Environmental education research, 8(3), 239260.

Kong, Y., \& Zhang, L. (2014). When does green advertising work? The moderating role of product type. Journal of Marketing Communications, 20(3), 197-213.

Kreps, T. A., \& Monin, B. (2011). "Doing well by doing good"? Ambivalent moral framing in organizations. Research in Organizational Behavior, 31, 99-123.

Lee, S. A., \& Oh, H. (2014). Effective Communication Strategies for Hotel Guests' Green Behavior. Cornell Hospitality Quarterly, 55(1), 52-63.

Lowry, P. B., Roberts, T. L., \& Higbee, T. (2007). First impressions with websites: The effect of the familiarity and credibility of corporate logos on perceived consumer swift trust of websites. In J. Jacko (Ed.), Human-Computer Interaction (pp. 77-85). Berlin: Springer.

Lynes, J. K., \& Andrachuk, M. (2008). Motivations for corporate social and environmental responsibility: A case study of Scandinavian Airlines. Journal of International management, 14(4), 377-390.

Lyon, T. P., \& Maxwell, J. W. (2011). Greenwash: corporate environmental disclosure under threat of audit. Journal of Economics \& Management Strategy, 20(1), 3-41.

Malone, S., McCabe, S., \& Smith, A. P. (2014). The role of hedonism in ethical tourism. Annals of Tourism Research, 44, 241-254.

Maniates, M. F. (2001). Individualization: Plant a tree, buy a bike, save the world? Global environmental politics, 1(3), 31-52.

Martens, C. (2008). Greenhushing..... Schhhhh. Retrieved July 16th, 2014. from http://www.kommunikationsforum.dk/artikler/greenhushing-schhhhh

Maxwell, J. A. (2012). Qualitative Research Design: An Interactive Approach: An Interactive Approach. Thousand Oaks, CA: Sage.

Miles, M., \& Huberman, A. (1994). Qualitative data analysis: an expanded sourcebook. Thousand Oaks, CA: SAGE.

Miller, G., Rathouse, K., Scarles, C., Holmes, K., \& Tribe, J. (2010). Public understanding of sustainable tourism. Annals of Tourism Research, 37(3), 627-645.

Mintel. (2007). Green and Ethical Consumers - UK - January 2007. London: Mintel International Group Limited.

Molina-Azorín, J. F., \& Font, X. (2016). Mixed methods in sustainable tourism research: an analysis of prevalence, designs and application in JOST (2005-2014). Journal of Sustainable Tourism, DOI: 
National Parks UK. (2015). National Parks: Britain's breathing spaces. RETRIEVED DATE ?from http://www.nationalparks.gov.uk/learningabout/whatisanationalpark/factsandfigures

PDNPA. (2014). Peak District National Park Visitor Survey 2014 \& Non-Visitor Survey 2014. from http://www.peakdistrict.gov.uk/ data/assets/pdf file/0005/538772/vistor-non-visitorsurvey-2014.pdf RETRIEVED DATE?

Peattie, K., \& Crane, A. (2005). Green marketing: legend, myth, farce or prophesy? Qualitative Market Research: An International Journal, 8(4), 357-370.

Pollay, R. W., \& Gallagher, K. (1990). Advertising and cultural values: Reflections in the distorted mirror. International Journal of Advertising, 9, 361-374.

Prothero, A., McDonagh, P., \& Dobscha, S. (2010). Is green the new black? Reflections on a green commodity discourse. Journal of Macromarketing, 30(2), 147-159.

Punch, K. F. (2013). Introduction to social research: Quantitative and qualitative approaches. Thousand Oaks, CA: Sage.

Pustejovsky, J., Anick, P., \& Bergler, S. (1993). Lexical semantic techniques for corpus analysis. Computational Linguistics, 19(2), 331-358.

Reed, D. (2013). Structural Adjustment, the Environment and Sustainable Development. London: Routledge.

Reiser, A., \& Simmons, D. G. (2005). A quasi-experimental method for testing the effectiveness of ecolabel promotion. Journal of Sustainable Tourism, 13(6), 590-616.

Sampaio, A., Thomas, R., \& Font, X. (2012). Small Business Management and Environmental Engagement. Journal of Sustainable Tourism, 20(2), 179 - 193.

Saxena, G. (2005). Relationships, networks and the learning regions: case evidence from the Peak District National Park. Tourism Management, 26(2), 277-289.

Schoeneborn, D., \& Trittin, H. (2013). Transcending transmission: Towards a constitutive perspective on CSR communication. Corporate Communications: An International Journal, 18(2), 193211.

Smith, T. M. (1998). The myth of green marketing: tending our goats at the edge of apocalypse. Toronto: University of Toronto Press.

Taylor, S., \& Bogdan, R. (1998). Introduction to qualitative methods: A guide and resource. New York: Wiley.

Tenbrunsel, A. E., \& Messick, D. M. (2004). Ethical fading: The role of self-deception in unethical behavior. Social Justice Research, 17(2), 223-236.

Tversky, A., \& Kahneman, D. (1981). The framing of decisions and the psychology of choice. Science, $211,453-458$.

Urry, J. (1990). The tourist gaze. London: Sage.

Villarino, J., \& Font, X. (2015). Sustainability marketing myopia: the lack of persuasiveness in sustainability communication Journal of Vacation Marketing, 21(4), 326-335.

Wehrli, R., Priskin, J., Demarmels, S., Schaffner, D., Schwarz, J., Truniger, F., \& Stettler, J. (2014). How to communicate sustainable tourism products to customers: results from a choice experiment. Current Issues in Tourism(ahead-of-print), 1-20.

Wengao, G. (2009). Linguistic variation and identity representation in personal blogs: A corpuslinguistic approach. (PhD thesis), National University of Singapore, http://scholarbank.nus.sg/handle/10635/18620, Retrieved: 16th December 2015, Singapore.

Yaeger-Dror, M., Granadillo, T., Takano, S., \& Hall-Lew, L. (2010). The Sociophonetics of Prosodic Contours on NEG in Three Language Communities: Teasing apart Sociolinguistic and Phonetic Influences on Speech. In D. R. Preston \& N. Niedzielski (Eds.), A Reader in Sociophonetics (pp. 133-176). New York: Walter de Gruyter Inc. 